\title{
EFEKTIVITAS PENGAWASAN BADAN PERMUSYAWARATAN DESA (BPD) TERHADAP PENGELOLAAN DANA DESA (DESA BLAHKIUH, KECAMATAN ABIANSEMAL, KABUPATEN BADUNG)
}

\author{
I Komang Gerdion Ananda Junior, I Ketut Kasta Arya Wijaya \& I Wayan Arthanaya \\ Fakultas Hukum Universitas Warmadewa, Denpasar-Bali, Indonesia \\ gerdionjr@gmail.com, kastaaryawijaya@gmail.com, arthanaya.wayan@gmail.com
}

\begin{abstract}
Abstrak
Dana desa merupakan bentuk dukungan yang diberikan oleh pemerintah dan sebagai sarana untuk mendorong dan mendukung pengembangan dan pemberdayaan masyarakat desa, bantuan tersebut digunakan untuk menunjang fasilitas masyarakat untuk mengembangkan kegiatan dan potensi desa. Anggaran pemerintah yang dialokasikan ke desa pada dasarnya digunakan untuk meningkatkan pengembangan dan pemberdayaan masyarakat. Tujuan penelitain ini adalah untuk mengkaji bentuk pengawasan Badan Permusyawaratan Desa (BPD) terhadap pengelolaan dana desa di Desa Blahkiuh dan bagaimana efektivitas pengawasan Badan Permusyawaratan Desa (BPD) terhadap pengelolaan dana desa di Desa Blahkiuh. Jenis penelitian yang digunakan dalam penelitian ini adalah metode empiris dengan menggunakan pendekatan sosiologis dan pendekatan perundang-undangan. Hasil penelitian ini menunjukkan bahwa Pelaksanaan pengawasan BPD terhadap pengelolaan dana desa di Desa Blahkiuh antara lain diarahkan untuk mewujudkan keadaan masa depan yang diinginkan dengan melihat potensi dan kebutuhan Desa. Efektivitas pengawasan BPD terhadap pengelolaan dana desa di Desa Blahkiuh antara lain belum sepenuhnya berjalan baik, walaupun anggaran pendapatan belanja desa sangat penting seperti kegiatan pembangunan/ perbaikan/ pemeliharaan untuk saluran irigasi, jalan, dll. Hal ini dipengaruhi oleh rendahnya partisipasi masyarakat, lemahnya koordinasi antara perencanaan dan pelaksanaan anggaran.
\end{abstract}

Kata Kunci : Badan Permusyawaratan Desa, Dana Desa, Pengawasan.

\begin{abstract}
Village funds are a form of assistance from the government as a means of support and means of encouraging development and empowerment of communities in the village, where the assistance is used to support community facilities in developing activities and potential in a village. The government budget given to the village is basically used to increase community development and empowerment. The purposes of this research are to examine the implementation of the supervision of the Village Consultative Body (BPD) on the management of village funds in Blahkiuh Village and the effectiveness of the supervision of the Village Consultative Body (BPD) on the management of village funds in Blahkiuh Village. This type of research used in this study is an empirical method, wtih socilogical approach and staturory approach. The results shows that Implementation of BPD supervision of village fund management in Blahkiuh Village, among others, is directed at realizing the desired future state by looking at the potential and needs of the Village. The effectiveness of BPD supervision on the management of village funds in Blahkiuh Village, among others, is not yet fully running, although the village budget is very important, such as construction / repair / maintenance activities for irrigation channels, roads, etc. This is influenced by low public participation, weak coordination between planning and budget execution. Keywords: Supervision, Village Consultative Body, Village Fund
\end{abstract}

\section{PENDAHULUAN}

Pasal 1 ayat 4 Undang-Undang Nomor 6 Tahun 2014 tentang Desa menjelaskan pengertian dari muatan lain yaitu nama Badan Permusyawaratan Desa atau badan lain yang merujuk pada penyelenggaraan fungsi pemerintahan, dan anggotanya merupakan perwakilan daerah yang diwakili. sesuai dengan regulasi. Sistem penduduk pedesaan ditentukan oleh demokrasi. Lurah memiliki posisi strategis sebagai penyelenggara tata kelola desa dan kota. Namun dalam 
menjalankan kekuasaan desa, posisi kedua lembaga tersebut sama, yaitu kepala desa dan BPD. Berdasarkan Pasal 26 ayat (1) UU No. 6 Tahun 2014, tanggung jawab kepala desa adalah mengurus pemerintahan desa, membangun desa, memajukan pembangunan masyarakat desa, dan memberdayakan masyarakat desa. Dalam Pasal 27, badan Kepala Desa harus :

1. Menyampaikan laporan pengelolaan desa kepala Bupati/Walikota rutin pada akhir Tahun anggaran;

2. Di akhir masa jabatan, menyampaikan laporan pemerintah desa kepada bupati / walikota;

3. Pada akhir setiap tahun anggaran, memberikan pernyataan administrasi pemerintah secara tertulis kepada badan konsultasi pedesaan; dan

4. Pada akhir setiap tahun anggaran, berkaitan dan/atau sebarkan informasi tertulis pengelolaan pemerintah kepada masyarakat pedesaan.

BPD jadi mitra kerja pemerintah desa yang sederajat dengan lembaga pemerintahan desa, serta bisa melaksanakan guna selaku lembaga yang mengawasi penyelenggaraan pemerintahan desa. Menurut kedudukan tersebut, tugas pokok BPD adalah merumuskan peraturan (fungsi Legislasi) yang dibutuhkan desa, yang disahkan atas perintah kepala desa, dan kepala desa menyusun anggaran pemasukan dan pengeluaran desa (penyusunan anggaran). Fungsi dan mengawasi kepala desa (kepala desa dan jabatannya) (fungsi control) dalam penyelenggaraan pemerintahan sehari-hari (Mamesah, 2015).

Dana desa merupakan bentuk dukungan yang diberikan oleh pemerintah dan sebagai sarana untuk mendorong dan mendorong pengembangan dan pemberdayaan masyarakat desa, bantuan tersebut digunakan untuk menunjang fasilitas masyarakat untuk mengembangkan kegiatan dan potensi desa. Anggaran pemerintah yang dialokasikan ke desa pada dasarnya digunakan untuk meningkatkan pengembangan dan pemberdayaan masyarakat. Dana desa harus digunakan dan disalurkan sesuai dengan peraturan perundang-undangan yang berlaku yang ditetapkan oleh pemerintah Indonesia. Dengan adanya regulasi tersebut diharapkan desa dapat dibagun sesuai dengan kebutuhan daerahnya. Saat menggunakan dana tingkat desa tersebut, diperlukan badan konsultasi tingkat desa (BPD) sebagai pengawasan, agar dana tersebut dapat digunakan secara jelas untuk pembangunan di tingkat desa.

Namun dalam hal pengawasan dana di tingkat desa, laporan pertanggungjawaban sistem di tingkat desa belum sepenuhnya dilaksanakan sesuai dengan standar berikut, dan mudah untuk memanipulasi data. Dana yang terkumpul di tingkat desa tidak dapat sepenuhnya mencerminkan kebutuhan desa. Oleh karena itu, perlu dirumuskan aturan dan sistem yang jelas untuk mengawasi dana tingkat desa dari Badan Permusyawaratan Desa (BPD) guna mengontrol proyek yang didanai oleh Dana Desa yang dirumuskan sesuai dengan Undang-Undang Nomor 43 Tahun 2014 kepada mencegah aparat melakukan penggelapan dana pemerintah tingkat desa di tingkat desa.

Ada beberapa peneltian terdahulu yang membahas mengenai pengelolaan dana desa. Yulistina \& Andirianto (2019) menjelaskan mengenai optimalisasi hak dan fungsi Badan Pemusyawaratan Desa (BPD) sebagai upaya meningkatkan kulitas penggunaan dana desa. Kemudian, Roza \& Arliman (2017) membahas peran Badan Pemusyawaratan Desa dalam pembangunan serta pengawasan keuangan desa. Dibentuknya badan ini agar dapat mengungkap fenomena yang terjadi dimasyarakat (Wibisono, 2017).

\section{METODE PENELITIAN}

Jenis penelitian yang akan digunakan dalam penelitian hukum ini adalah metode empiris. Ilmu hukum empiris adalah ilmu hukum yang memandang hukum sebagai fakta yang dapat terikat atau ditaati dan tidak memiliki nilai (Nasution, 2008). Penelitian hukum empiris digunakan untuk menganalisis hukum, yang dianggap sebagai tingkah laku biasa yang selalu berinteraksi dengan masyarakat dan berkaitan dengan aspek sosial dalam kehidupan, dengan menggunakan pendekatan sosiologis dan pendekatan perundang-undangan (Sunggono, 2016). 


\section{HASIL DAN PEMBAHASAN}

\section{Pelaksanaan Pengawasan Badan Permusyawaratan Desa (BPD) Terhadap Pengelolaan Dana Desa di Desa Blahkiuh}

Menurut Menteri Dalam Negeri Nomor 114 Tahun 2014 tentang Pedoman Pembangunan Perdesaan, perencanaan pembangunan perdesaan merupakan proses dari rangkaian kegiatan yang diselenggarakan oleh pemerintah desa. sumber daya pedesaan untuk mencapai tujuan pembangunan pedesaan. Dharma Setyawan Salam menyatakan bahwa kegiatan perencanaan adalah menghimpun pilihan dari berbagai pilihan yang tersedia untuk melakukan tindakan, termasuk strategi, kebijakan, rencana, proyek dan prosedur untuk mencapai tujuan organisasi (Putra et al., 2020).

Anggota badan musyawarah desa merupakan wakil dari masyarakat desa yang dibentuk di bawah sistem perwakilan daerah, yang menjabat selama enam tahun sejak tanggal sumpah. Anggota Komite Penasihat dapat dipilih untuk tiga periode berturut-turut. Ketentuan lain yang terkait dengan badan pembangunan pedesaan harus diatur dalam peraturan daerah / perkotaan.

Fungsi BPD adalah bekerja sama dengan kepala desa untuk merumuskan peraturan desa yang menyesuaikan dan memandu keinginan masyarakat. Selain itu, fungsi BPD juga termasuk memantau pelaksanaan peraturan desa sekaligus menentukan kinerja. dari pemerintah desa (Trisantono, 2011).

Dalam wawancara dengan Bapak Gusti Ngurah Made Oka, Penanggung Jawab Desa Blahkiuh mengatakan : kepala desa dan BPD menentukan peranan penyusunan "peraturan desa" dalam rencana kerja pemerintah desa. Organisasi masyarakat, Badan adat desa dan lembaga tingkat desa lainnya dapat memberikan nasehat tentang "penyusunan peraturan desa" kepada pemerintah desa dan / atau BPD. Pemerintah desa memprakarsai penyusunan "Peraturan Desa". Rancangan "Peraturan Desa" yang telah disusun harus dinegosiasikan dengan penduduk pedesaan, lalu dapat dinegosiasikan dengan penanggung jawab jalan untuk meminta pendapat. Rancangan undang-undang desa yang dikonsultasikan lebih diutamakan daripada masyarakat atau kelompok masyarakat terkait langsung dengan substansi materi undang-undang tersebut. Pemerintah desa dan perangkat desa memanfaatkan pendapat masyarakat desa untuk menindaklanjuti penyusunan "peraturan desa".

BPD membahas dan menyepakati rancangan "peraturan desa" dengan kepala desa. Dalam ini, pemerintah desa dan usulan Badan Permusyawaratan Desa membahas hal yang sama terlebih dahulu, Kemudian memprioritaskan rancangan peraturan desa yang diajukan oleh badan musyawarah desa, dan kepala desa mengusulkan "rancangan peraturan desa" digunakan sebagai bahan ujian. Pengusul biasa mencabut rancangan peraturan desa yang belum dibahas. Kecuali pemerintah desa dan Badan Permusyawaratan Desa saling bersepakat. "rancangan peraturan desa" yang sudah dibahas tidak bisa ditarik kembali.

Pengaturan finansial desa dilaksanakan bersumber pada atas praktik- praktik pemerintahan yang baik. Dasar-dasar pengaturan finansial desa sebagaimana diatur dalam syarat Permendagri No 113 Tahun 2014 ialah transparan, akuntabel, partisipatif dan dicoba dengan tertib serta disiplin anggaran. Penegasan atas asas pengelolaan keuangan desa dapat diuraikan sebagai berikut:

Satu jenis, Transparansi adalah prinsip keterbukaan yang memungkinkan rakyat tahu \& memperoleh keterangan mengenai keuangan pedesaan seluas-luasnya. Prinsip ini menaruh hak pada rakyat buat memperoleh keterangan yang benar, jujur dan tidak diskriminatif mengenai penyelenggaraan pemerintahan desa, tetapi tetap memperhatikan peraturan perundangundangan;

Akuntabilitas adalah bentuk pengelolaan dan pengendalian yang bertanggung jawab atas sumber daya yang dipercayakan dan strategi untuk mencapai tujuan yang telah ditentukan;

1. Partisipasi adalah pelaksanaan, termasuk badan desa;

2. Tata tertib anggaran, adalah pengaturan finansial pedesaan, patut bertujuan pada aturan yang menjadi dasarnya.

Pelaksanaan hak dan kekuasaan secara otonom dan kebebasan meninggalkan desa memerlukan tanggung jawab untuk menjaga keutuhan, persatuan, dan keutuhan negara dalam ruang lingkup 
Republik Indonesia, serta mengemban tanggung jawab untuk mewujudkan kemasyarakatan rakyat, kesejahteraan. Dalam ruang lingkup hukum dan peraturan saat ini. Setiap undangundang desa telah menjadi salah satu prinsip kemandirian desa yang mengatur masyarakat melalui otonomi.

\section{Efektivitas Pengawasan Badan Permusyawaratan Desa (BPD) Terhadap Pengelolaan Dana Desa di Desa Blahkiuh}

Kewenangan ialah kekuasaan membuat keputusan mengatur serta berikan tanggung jawab kepada orang lain. Kewenangan yakni kekuasaan yang diformalkan buat orang-orang tertentu maupun kekuasaan legislatif memberikan kekuasaan kepada pemerintah di bidang-bidang tertentu maupun dari pemerintah. Sanksi merupakan salah satu cara untuk memperkuat perilaku sipil tersebut Oleh karena itu sanksi merupakan bagian yang melekat pada norma hukum tertentu (Nono, M. A. K. S., Wijaya, I. K. K. A., \& Suryani, L. P. (2020).

Menurut Siagian, "Pengawasan adalah mengamati proses pelaksanaan semua kegiatan organisasi untuk memastikan bahwa semua pekerjaan dilaksanakan sesuai dengan rencana yang telah ditetapkan" (Siagian, 2010). Selain itu, Situmorang menambahkan : "pengawasan adalah segala upaya dan tindakan, tujuannya untuk menentukan tugas yang dilakukan sesuai dengan peraturan, tujuan yang ingin dicapai" (Situmorang, 2010). Dengan sistem pengawasan yang seimbang antara pemerintah desa dan lembaga desa sehingga kewenangan, kedudukan, dan keuangan desa bisa lebih kuat dan akuntabel. Badan Permusyawaratan Desa (BPD) dengan kedudukannya mempunyai tugas untuk merumuskan kebijakan pemerintah Desa dengan Kepala Desa, karena kepala desa yang dipilih melalui pemilu oleh masyarakat untuk menghindari kekacauan dalam pemerintahan Desa. BPD mesti mempunyai keinginan atau pemikiran yang sama dengan Kepala Desa (Rudiarta et al., 2020).

Dari sudut pandang diatas, dapat disimpulkan bahwa supervisi merupakan pernyataan yang pasti dan realistis dari tindakan yang dilakukan oleh manusia dalam suatu lembaga atau organisasi sendiri atau secara kelompok. Dana tingkat desa bersumber dari Anggaran Pendapatan dan Belanja Negara (APBN) yang merupakan perimbangan fiskal antara pemerintah pusat dan pemerintah daerah (dikurangi alokasi khusus), yaitu 10\% dari dana tersebut digunakan untuk mendanai rencana pembangunan tingkat desa. Menyesuaikan dan membagi besaran dana desa menurut jumlah penduduk, luas wilayah, tingkat kemiskinan dan tingkat kesulitan daerah. Selain pembelian dana dari APBN, dana desa juga bersumber dari anggaran belanja daerah dan swadaya masyarakat.

Dalam terwujudnya organisasi yang efektif, perwujudan fungsinya tidak lepas dari berbagai faktor yang mempengaruhi kinerjanya dalam mencapai tujuannya. Seperti halnya Badan Permusyawaratan Desa, untuk mencapai hasil yang efektif dan baik, tidak hanya itu yang akan terjadi, tetapi juga beberapa faktor yang akan mempengaruhinya. Berikut hasil wawancara dengan pejabat pemerintah, Kepala Desa Blahkiuh, mengenai kendala yang dihadapi BPD dalam menjalankan tugas pokoknya. Ia mengatakan : BPD sering menemui kendala dalam menjalankan tugasnya. Fungsinya kurang. Fasilitas usaha BPD memberikan lebih sedikit subsidi dan kurangnya pelatihan dan konsultasi tentang pemerintahan desa.

Seperti yang dikatakan Ketua Made Sukarsa, kendala lain juga ada, yaitu:

1. Masih banyak desa terutama yang jauh dari perkotaan yang masih kurang transparan secara finansial;

2. Banyak desa yang belum membentuk komite informasi tentang dana dan anggaran desa, juga belum membentuk komite informasi proyek pembangunan. Sekelompok kecil masyarakat menggunakan fasilitas meunasah/ masjid dengan menyatakan secara langsung penggunaan dana desa;

3. Dalam beberapa kasus, partisipasi masyarakat ditemukan rendah, terutama partisipasi perempuan dalam perencanaan dan penggunaan dana pedesaan. Bahkan, di beberapa desa, pengelolaan dana desa dikuasai oleh keluarga perangkat desa;

4. Karena aturan dan regulasi yang sangat ketat dan rumit, pengelolaan dana desa oleh masyarakat kurang kreatif; 
5. Pengawasan yang ketat untuk membuat masyarakat khawatir tentang penggunaan dana desa;

6. Persyaratannya kompleks, sehingga desa sulit untuk memenuhi persyaratan tersebut tepat waktu, sehingga potensi silpa setiap tahun ada.

Kendala yang menghalangi Badan Permusyawaratan Desa (BPD) Desa Blahkiuh berperan sebagai pengawas dalam mengelola alokasi dana desa Di Desa Blahkiuh yaitu perasaan segan antara BPD dengan perangkat desa dikarenakan masih ada hubungan saudara dan kekeluargaan. Selain itu juga kurangnya partisipasi masyarakat desa dalam hal kepedulian terhadap pengelolaan ADD di Desa Blahkiuh.

Hal ini disampaikan oleh Bapak Gusti Ngurah Made Oka, Kepala Desa Blahkiuh, yang menyatakan : hambatannya kalau bisa dibilang seperti ini, disini kita semua keluarga, kita disini yang menjabat jugakan merupakan putra-putri terbaik daerah. Jadi kita disini tetap saling mendukung dan jangan menjatuhkan.Tapi mendukung dalam hal yang positif. Dalam masalah pengawasan disini sebenarnya karena kita masih ikatan saudara disini semua, jadi seperti ada rasa segan atau tidak enak. Namun, pengawasan tetap kita jalankan. Kalau, terbukti salah, ya kita salahkan. Sejauh ini seperti yang saya katakana masih baik-baik saja, adapun kesalahan yang ditemui masih dalam kewajaran yang masih bisa diselesaikan secara kekeluargaan. Jadi disini sama-sama lah menghindari kecurangan-kecurangan untuk sama-sama menjaga nama desa. Selain itu hambatannya, dari pihak masyarakat sendiri juga untuk kepedulian terhadap dana desa ini sangat minim. Sebagian besar masyarakat tidak mau tau tentang pengelolaan dana desa ini. Ya walau bagaimanapun, peran masyarakat dan partisipasinya juga diperlukan. Kirakira inilah hambatan yang mungkin selama ini kami hadapi.

Berdasarkan hal tersebut, penulis dapat menjelaskan bahwa pengawasan harus dapat membuktikan derajat kecocokan dan ketidaksesuaian, serta mengetahui penyebab ketidaksesuaian tersebut. Terhadap penanganan finansial di Desa Blahkiuh melainkan digunakan untuk kegiatan pembangunan/ perbaikan/pemeliharaan digunakan untuk belanja saluran irigasi, jalan, pembangunan sarana air bersih termasuk belanja pembinaan dan/atau pemberdayaan kegiatan kemasyarakatan, hal ini juga dipengaruhi oleh rendahnya partisipasi masyarakat, lemahnya koordinasi antara perencanaan dan pelaksanaan anggaran. Dalam terwujudnya organisasi yang efektif, dalam pelaksanaan fungsinya tidak lepas dari berbagai faktor yang mempengaruhi kinerjanya dalam mencapai tujuannya. Seperti halnya lembaga musyawarah pedesaan, untuk mencapai hasil yang efektif dan baik, tidak hanya akan terjadi, tetapi beberapa faktor akan mempengaruhinya. Berikut gambaran unsur-unsur penyelenggaraan pemerintahan. Kepala Desa Blahkiuh menyampaikan kendala yang dihadapi BPD dalam menjalankan tugas pokoknya. Ia mengatakan : BPD sering menemui beberapa kendala dalam menjalankan fungsinya yaitu kurangnya fasilitas operasional BPD, tunjangan kurangnya pelatihan dan konsultasi tentang pengelolaan desa.

\section{SIMPULAN DAN SARAN}

\section{Simpulan}

Berdasarkan uraian tersebut diatas dapat ditarik simpulan bahwa Badan Permusyawaratan Desa (BPD) dapat terus melakukan pemeriksaan terhadap pengaturan finansial desa Desa Blahkiuh dengan pendampingan berkelanjutan yang diberikan oleh Badan Permusyawaratan Desa (BPD). Dana yang ada di desa dikelola oleh desa dan tidak akan disalahgunakan atau disalahgunakan, sehingga pembangunan desa dapat terwujud dan Badan Permusyawaratan Desa (BPD) tidak bekerja dengan sebagaimana mestinya dalam pengawasan pengaturan dana desa di Desa Blahkiuh, hal ini disebabkan oleh partisipasi masyarakat yang rendah, fasilitas operasional BPD yang kurang, subsidi yang tidak mencukupi, kurangnya pelatihan dan konsultasi tentang pengelolaan desa, perencanaan dan pelaksanaan anggaran kurangnya koordinasi antara. 


\section{Saran}

Berdasarkan kesimpulan tersebut diatas maka penulis dapat memberikan saran sebagai berikut:

1. Dapat disarankan kepada pemerintahan desa bahwa sebelum dilakukannya musyawarah desa untuk menentukan APBDesa, akan menjadi lebih baik apabila masyarakat diberikan informasi atau pemahaman terkait arti penting adanya musyawarah desa, karena dengan aktifnya partisipasi masyarakat maka akan didapat informasi kebutuhan yang lebih banyak sehingga forum musyawarah desa dapat menganalisa serta menentukan pembangunan dan/atau pengadaan skala prioritas yang sangat dibutuhkan dan skala lanjutan yang juga harus dipenuhi, sehingga pembangunan menjadi produk yang dapat bermanfaat bagi masyarakat desa.

2. Dapat disarankan kepada pemerintah desa terkait dengan serapan APBDes untuk tetap melaksanakan ketentuan peraturan perundang-undangan di dalam melaksanakan anggaran desa, penetapan lokasi sehingga serapan anggaran tetap dapat terwujud sesuai peruntukan, kebutuhan dan memberi nilai manfaat bagi masyarakat desa. Serapan dengan jujur dan transparan tanpa tindakan korupsi akan membantu pelaksanaan serapan anggaran sesuai dengan tujuan yang telah ditentukan dalam musyawarah desa.

\section{DAFTAR PUSTAKA}

Nasution, B. J. (2008). Metode Penelitian Hukum. Mandar Maju, Bandung.

Mamesah, F. Y. (2015). Peranan Badan Permusyawaratan Desa dalam Penyusunan Anggaran Pendapatan dan Belanja Daerah (Desa Sendangan, Kecamatan Tompaso). Fakultas Hukum, Universitas Sam Ratulangi Manado.

Putra, I. M. R., Arthanaya, I. W., \& Suryani, L. P. (2020). Hubungan Fungsional Desa Pakraman dengan Desa Dinas dalam Pelaksanaan Pembangunan di Desa Pererenan Menurut UU No. 6 Tahun 2014. Jurnal Konstruksi Hukum, Vol.1(2).

Rudiarta, I. K. G., Arthanaya, I. W., \& Suryani, L. P. (2020). Pengelolaan Alokasi Dana Desa dalam Pemerintahan Desa. Jurnal Analogi Hukum, Vol.2(1).

Roza, D., \& Arliman, L. (2017). Peran Badan Permusyawaratan Desa Di Dalam Pembangunan Desa Dan Pengawasan Keuangan Desa. Jurnal Ilmu Hukum, Vol.4(3).Siagian, S. P. (2010). Manajemen Sumber Daya Manusia. Bumi Aksara, Jakarta.

Situmorang. (2010). Analisis Data Penelitian (Cet.2). USU Press, Medan.

Sunggono, B. (2016). Metodologi penelitian hukum (Cet.15). PT RajaGrafindo Persada, Jakarta.

Trisantono, B. (2011). No Pedoman Penyelenggaraan Pemerintahaan Desa. Fokusmedia, Bandung.

Wibisono, N. (2017). Mengungkap Fenomena Pengawasan Publik Terhadap Dana Desa Di Kabupaten Madiun. Jurnal AKSI, Vol.2(2).

Yuliastina, R., \& Andiriyanto, A. (2019). Optimalisasi Hak Dan Fungsi Badan Permusyawaratan Desa (Bpd) Sebagai Upaya Meningkatkan Efektifitas Penggunaan Dana Desa (Dd) Dan Alokasi Dana Desa (Add) Di Kabupaten Sumenep. Jurnal Dinamika Governance, Vol.9(1). 